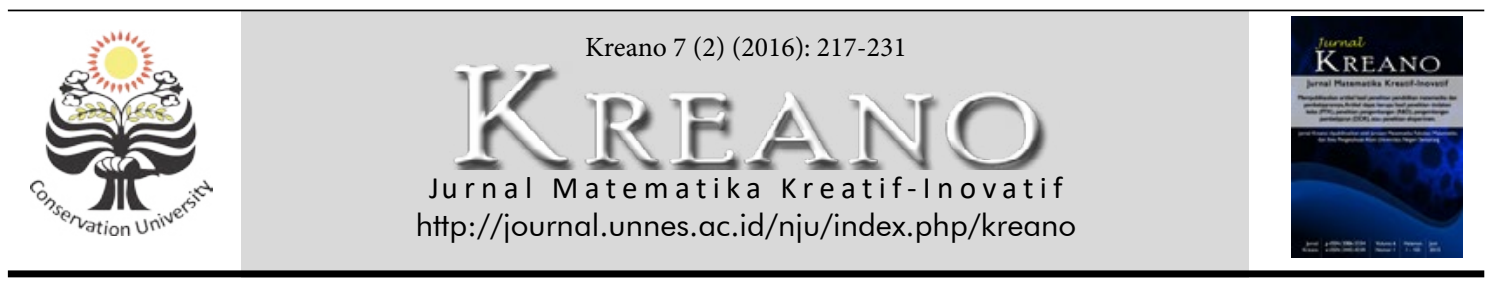

\title{
Analisis Time-Line dan Berpikir Kritis dalam Pemecahan Masalah Matematika pada Pembelajaran Kooperatif Resiprokal
}

\author{
'Rochmad, 'A. Agoestanto, dan 'A.W. Kurniasih \\ 'Jurusan Matematika FMIPA, Universitas Negeri Semarang, Indonesia \\ Email: rachmadmanden@yahoo.com \\ DOI: http://dx.doi.org/10.15294/kreano.v7i2.4980 \\ Received: February, 2016; Accepted: May, 2016; Published: December, 2016
}

\begin{abstract}
Abstrak
Tujuan penelitian ini adalah mengetahui grafik time-line dalam diskusi untuk pemecahan masalah opened-ended dalam pembelajaran kooperatif resiprokal, mendeskripsikan langkah-langkah kegiatan pemecahan masalah open-ended dalam diskusi kelompok pada pembelajaran kooperatif resiprokal, dan mendeskripsikan karakteristik berpikir kritis siswa dalam menyelesaikan masalah open-ended. Penelitian ini merupakan penelitian kualitatif.

Kegiatan pada penelitian ini adalah pembelajaran resiprokal 2 kali untuk mendapatkan data time-line tahap berpikir kritis dan time-line aktivitas pemecahan masalah matematika, tes berpikir kritis 2 kali, analisis karakteristik berpikir kritis berdasarkan tes 1 dan 2. Sumber data dalam penelitian ini adalah siswa kelas VIII di SM P Negeri 1 Ngadirejo Temanggung. Hasil penelitian ini adalah 4 kelompok diskusi melakukan tahap strategi pada berpikir kritis lebih lama dibandingkan tahap berpikir kritis lainnya (klarifikasi, simpulan, dan strategi. Untuk memecahkan masalah matematika, pada langkah pertama yaitu memahami masalah. Pada langkah ini siswa dominan melakukan aktivitas bertanya dan memprediksi. Pada langkah kedua yaitu merencanakan penyelesaian, siswa dominan melakukan kegiatan bertanya dan menjelaskan. Pada langkah ketiga yaitu melaksanakan penyelesaian, siswa dominan melakukan kegiatan menjelaskan dan bertanya. Sedangkan pada langkah keempat yaitu mengecek kembali, siswa dominan melakukan kegiatan menjelaskan.
\end{abstract}

\begin{abstract}
The purpose of this study was to determine the chart time-line in the discussion for troubleshooting opened-ended in cooperative learning reciprocal, describe the steps to solving open-ended discussion group on cooperative learning reciprocal, and describe the characteristics of students' critical thinking in problem solving open -ended. This research is qualitative. Activities in this study is a reciprocal learning 2 times to get data time-line phase of critical thinking and timeline activity mathematical problem solving, critical thinking test 2 times, analyzes the characteristics of critical thinking based on tests 1 and 2. The source of data in this study were students class VIII SMP Negeri 1 Temanggung Ngadirejo. The results of this study are four discussion groups to stage strategy on critical thinking longer than the stage of critical thinking more (clarification, conclusions, and strategies. To solve mathematical problems, the first step is to understand the problem. In this step students Dominant activities ask and predict . in the second step is to plan the completion, students are the dominant activities ask and explain. in the third step of carrying out the settlement, the students dominant activity explain and ask questions. While in the fourth step is to check back, student predominant activity explained.
\end{abstract}




\section{PENDAHULUAN}

Berdasar kurikulum 2013, salah satu kompetensi yang harus dikembangkan dalam pembelajaran matematika di SMP adalah kemampuan berpikir kritis dan kreatif. Pada jenjang SMP/MTs kemampuan berpikir kritis siswa tergolong rendah, khususnya pada kompetensi pemecahan masalah open-ended. Konsep-konsep dasar untuk dapat memecahkan masalah dengan baik diperlukan kemampuan berpikir kritis, dan kemudian memungkinkan siswa berpikir kreatif. Untuk belajar matematika di tingkat SMP/MTs kemampuan berpikir kritis mendahului kemampuan berpikir kreatif. Pada prinsipnya kurikulum 2013 untuk membangun para siswa mampu berpikir kreatif. Karena dalam matematika kemampuan berpikir kritis bagi siswa dipandang sebagai dasar untuk dapat berpikir kreatif, maka dalam penelitian ini memfokuskan pada penyelidikan berpikir kritis siswa dalam memecahkan masalah matematika open-ended.

Fakta di lapangan kemampuan berpikir kritis siswa dalam kategori rendah. Sebagai contoh ketika siswa di suatu kelas VII SMPN 2 Temanggung diminta menilai benar atau salah pernyataan: "persegi adalah persegi panjang," dari zo siswa yang menjawab "benar bahwa persegi adalah persegi panjang" hanya dua siswa. Ini mengindikasikan sebagian besar siswa belum dapat berpikir kritis dalam hal menghubungkan konsep persegi panjang dan persegi. Siswa masih tercekat dengan masalah kontekstual, yakni apa yang dilihat bukan apa yang ada dalam "pikiran" tentang definisi "persegi panjang" dan "persegi." Dalam pikiran siswa tidak "kritis," yakni tidak mengerti bahwa "persegi adalah persegi panjang yang semua sisinya sama panjang." Akibatnya lebih lanjut siswa juga tidak mengerti bahwa himpunan semua persegi adalah himpunan bagian dari himpunan semua persegi panjang.

Berkaitan dengan kemampuan berpikir kritis dan kreatif siswa SMP. Berikut ini ilustrasi dari hasil analisis kemampuan berpikir kreatif siswa yang datanya diperoleh melalui tes dan wawancara. Analisis sederhana tentang pemecahan masalah luas daerah segitiga yang hasilnya secara kualitatif menunjukkan siswa kurang kritis dan kreatif.
Soal "Jajargenjang dengan sisi $29 \mathrm{~cm}$ dan 17 $\mathrm{cm}$, serta tingginya $19 \mathrm{~cm}$. Berapakah luas jajargenjang tersebut?"

Seorang siswa menggambar sketsa situasi dari masalah tersebut sebagai berikut.

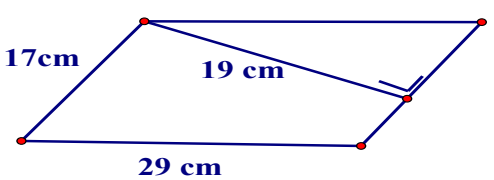

Luas $=17 \times 19=323$

Jadi luas jajargenjang $=323 \mathrm{~cm}^{2}$.

Berdasar hasil kerja siswa tersebut, para siswa diminta menganalisis dan mengevaluasi kebenaran/kesalahan jawabannya. Dan kepada siswa diajukan pertanyaan sebagai berikut. Pahami masalahnya, cermati sketsa gambar tersebut.

(1) Jika Anda berpendapat sketsa gambar itu benar, tulislah alasannya!

(2) Jika Anda berpendapat sketsa gambar itu salah, tulislah alasannya; dan betulkan agar sketsa gambarnya benar!

Hasil dari jawaban siswa sebagai berikut. Hampir semua siswa kelas VIII menyatakan sketsa gambar sudah benar, tidak ada kesalahan, dan luasnya $323 \mathrm{~cm}^{2}$ sudah benar. Guru mengatakan sketsa gambar itu salah! Sekali lagi, para siswa diminta menganalisis dan mengevaluasi mengapa jawaban siswa tersebut salah. Tak satupun siswa mengetahui bahwa pekerjaan siswa (atau dirinya) itu salah. Ini mengindikasikan kemampuan berpikir kritis siswa dalam kategori "kurang." Ada siswa yang mencoba membetulkan sketsa gambar menjadi sebagai berikut.

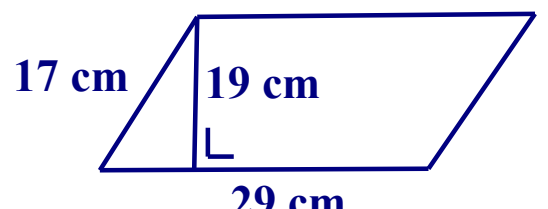

Pembetulan ini menjadi "semakin" salah, mustahil dalam suatu segitiga siku-siku panjang proyeksinya lebih panjang dari sisi miringnya. 
Pemikiran siswa kurang mampu mengaitkan antara beberapa konsep matematika, misalnya Teorema Pytahgoras dan situasi nyata (kontekstual). Ini mengindikasikan kekurangkritisan siswa dalam memecahkan masalah. Dalam desain sebenarnya, misalnya dalam konstruksi jaringan permesinan sketsa gambar tersebut "tidak dapat dibuat," panjang titik proyeksi ke salah satu titik sudut jajargenjang mustahil kurang dari $17 \mathrm{~cm}$.

Doolittle et al, (2006), mengemukakan pengertian pembelajaran resiprokal adalah strategi pembelajaran yang berdasar pada pemodelan dan petunjuk praktis, yakni mulamula instruktur, guru, atau dosen mula-mula menjadi model dan kemudian secara bertahap tanggungjawab menjadi model beralih pada siswa atau siswa. Pembelajaran kooperatif awalnya dikemukakan oleh Palainscar dan Brown yang mengutamakan kerja kelompok dalam memecahkan suatu masalah, dalam 'kooperatif' yakni kerja kelompok didesain dengan memperhatikan aspek-aspek 'resiprokal' yaitu meringkas (summaries), menanya (question), menjelaskan (clarify), dan memprediksi (predict).

Untuk dapat mengatur diskusi kelompok untuk memecahkan masalah matematika dengan baik diperlukan time-line. Timeline memberikan struktur. Terdapat berbagai bentuk visualisasi time-line misalnya grafik horisontal, vertikal, spiral, atau lingkaran; bahkan dapat digunakan peta. Siswa atau mahasiwa dalam diskusi kelompok akan menjadi lebih efektif jika mampu membagi waktu dalam bentuk time-line. Kebiasaan ini perlu ditumbuhkan agar dapat meningkatkan kualitas diskusinya.

Menurut The Critical Thinking Task Force of the South Carolina Higher Education Assessment Network, Berpikir kritis adalah penggunaan representasi kognitif, proses dan strategi yang reflektif, sistematis, rasional dalam mengambil keputusan (Cook, Johnson, Moore, Myers, Pauly, Pendavris, et al., dalam Palmer, 2007). Menurut Ennis (1996) definisi berpikir kritis adalah "critical thinking is reasonable, reflektive thinking that is focused on deciding what to believe or do". Menurut definisi ini, berpikir kritis menekankan pada berpikir secara beralasan dan reflektif. Berpikir yang masuk akal dan reflektif ini digunakan untuk mengambil keputusan.

Pada saat berpikir kritis, seseorang akan melalui suatu tahapan berpikir. Menurut Perkins \& Murphy (2006) berpikir kritis melalui 4 tahap penting yaitu klarifikasi, evaluasi, penyimpulan dan strategi/taktik. Tahap kemampuan berpikir kritis pada penelitian ini adalah adalah langkah-langkah berpikir kritis yang mencakup kemampuan klarifikasi, evaluasi, penyimpulan, strategi/taktik. Tahap klarifikasi merupakan tahap menyatakan, mengklarifikasi,menggambarkan atau mendefinisi masalah. Tahap evaluasi merupakan tahap menilai aspek-aspek seperti membuat keputusan pada situasi, mengemukakan fakta-fakta argumen atau menghubungkan masalah dengan masalah yang lain. Tahap penyimpulan tahap dimana siswa dapat menunjukkan hubungan diantara sejumlah ide, menggambarkan kesimpulan yang tepat dengan deduksi dan induksi, menggeneralisasi, menjelaskan dan membuat hipotesis. Tahap strategi/taktik merupakan tahap mengajukan, mengevaluasi sejumlah tindakan yang mungkin.

Menurut Jacob (2012), indikator dari klarifikasi adalah 1) menganalisis, mendiskusikan ruang lingkup masalah, 2) mengidentifikasi satu atau lebih asumsi dari masalah, 3) mengidentifikasi hubungan antara bagian satu dengan bagian lain dari masalah, 4) mendefinisikan istilah yang relevan. Indikator dari evaluasi adalah 1) mendapatkan dan menilai informasi yang relevan, 2) menanyakan apakah penalaran valid atau relevan, 3) membuat keputusan berdasarkan kriteria penilaian/ argmen/situasi. Indikator simpulan adalah 1) membuat deduksi yang tepat berdasarkan hasi diskusi, 2) memunculkan pemikiran, 3) membuat generalisasi dari hasil-hasil yang relevan, 4) membuat kerangka hubungan diantara bagian-bagian masalah yang berbeda. Indikator strategi adalah 1) mengajukan langkah-langkah tertentu untuk mendapatkan penyelesaian, 2) mendiskusikan langkahlangkah yang mungkin muncul, 3) mengevaluasi langkah-langkah yang mungkin, 4) memprediksi hasil.

Pada penelitian ini, indikator dari tahap klarifikasi adalah mendefinisikan istilah yang 
relevan. Indikator tahap evaluasi adalah mendapatkan dan memberikan informasi yang relevan. Indikator tahap simpulan adalah membuat kerangka hubungan diantara bagian-bagian masalah yang berbeda. Indikator tahap strategi adalah mengajukan langkahlangkah tertentu untuk mendapatkan penyelesaian.

Krulik dan Rudnick (1995) mendefinisikan masalah sebagai suatu situasi, besaranbesaran atau yang lainnya yang dihadapkan pada individu atau kelompok siswa, yang menuntut mencari pemecahan kembali (resolve) yang untuk pencarian itu para individu tidak segera tahu cara menemukan solusinya. Dengan menggunakan definisi masalah seperti ini, pemecahan masalah dipandang sebagai suatu proses dan didefinisikan sebagai penggunaan secara individu dari pengetahuan, keterampilan, pemahaman yang dimiliki sebelumnya untuk memenuhi permintaan dari situasi yang tidak begitu dikenal.

Menurut Polya sebagai mana dikutip oleh Hudojo (2003), terdapat empat langkah yang harus dilakukan untuk memecahkan suatu masalah yaitu memahami masalah, merencanakan penyelesaian, menyelesaikan masalah sesuai rencana, dan pengecekan kembali terhadap semua langkah yang telah dikerjakan. Penelitian Schoenfeld (1992) berkaitan dengan time-line siswa dalam diskusi berpasangan memecahkan masalah dan hasilnya diwujudkan dalam grafik horisontal time line meliputi aspek kegiatan membaca (read), menganalisis (analyze), mengeksplor (explore), merencanakan (plan), mengimplementasikan (implement), dan memverifikasi (verify). Hasil penelitiannya menunjukkan, jika masalah yang didiskusikan masalah matematika yang rutin (routin problem), siswa cenderung melakukan dua kegiatan: membaca dan mengeksplor. Tetapi jika masalah tidak rutin (non routin problem) maka semua aspek muncul.

Brown dan Palainscar, mengemukakan pengertian pembelajaran resiprokal adalah strategi pembelajaran yang berdasar pada pemodelan dan petunjuk praktis, yakni mulamula instruktur, guru, atau dosen mula-mula menjadi model dan kemudian secara bertahap tanggungjawab menjadi model beralih pada siswa atau siswa (Doolittle et.al., 2006). Menurut Reilly, Parsons, \& Bortolot (2009) urutan kegiatan dalam kerja kelompok adalah memprediksi, menjelaskan, bertanya, dan meringkas.

Berdasar uraian pada latar belakang ini, diperlukan penelitian di bidang pembelajaran matematika dengan judul: "Analisis Time-line dan Berpikir Kritis dalam Pemecahan Masalah Matematika Pada Pembelajaran Kooperatif Resiprokal." Masalah dalam penelitian ini disajikan dalam pertanyaan penelitian adalah (a) Bagaimana grafik time-line dalam diskusi untuk pemecahan masalah opened-ended?, (b) Bagaimana langkah-langkah kegiatan pemecahan masalah open-ended dalam diskusi kelompok pada pembelajaran kooperatif resiprokal?, dan (c) Bagaimana karakteristik berpikir kritis siswa dalam menyelesaikan masalah open ended?.

\section{METODE PENELITIAN}

Penelitian ini menggunakan pendekatan kualitatif yang akan menganalisis kemampuan berpikir kritis siswa kelas VIII SMP di Jawa Tengah. Penggunaan pendekatan kualitatif dengan alasan didasarkan pada definisi penelitian kualitatif yang dipaparkan oleh Moleong (2011) bahwa penelitian kualitatif adalah penelitian yang bermaksud untuk memahami fenomena tentang apa yang dialami oleh subjek penelitian yang terkait perilaku, persepsi, tindakan, dan lain-lain, secara holistik dan dengan cara deskripsi kata-kata dan bahasa, pada suatu konteks khusus yang ilmiah dan dengan memanfaatkan berbagai metode ilmiah.

Secara rinci alur penelitian ini digambarkan dalam Gambar 1.

Penelitian ini akan dilaksanakan di kelas VIII dari SMP Negeri 1 Ngadirejo Kabupaten Temanggung. Data kualitatif yang diperoleh dari hasil tes 1 dan 2 terhadap beberapa siswa masing-masing seorang perwakilan klasifikasi kemampuan berpikir kritis (tinggi, sedang, rendah) kelas VIII dan dilakukan secara mendalam untuk mengetahui tahap berpikir kritis. Selain itu juga data waktu siswa berpikir kritis dalam diskusi kelompok, data waktu siswa melakukan aktivitas pemecahan masalah dalam diskusi kelompok, serta data aspek pembelajaran resiprokal dalam langkah-lang- 


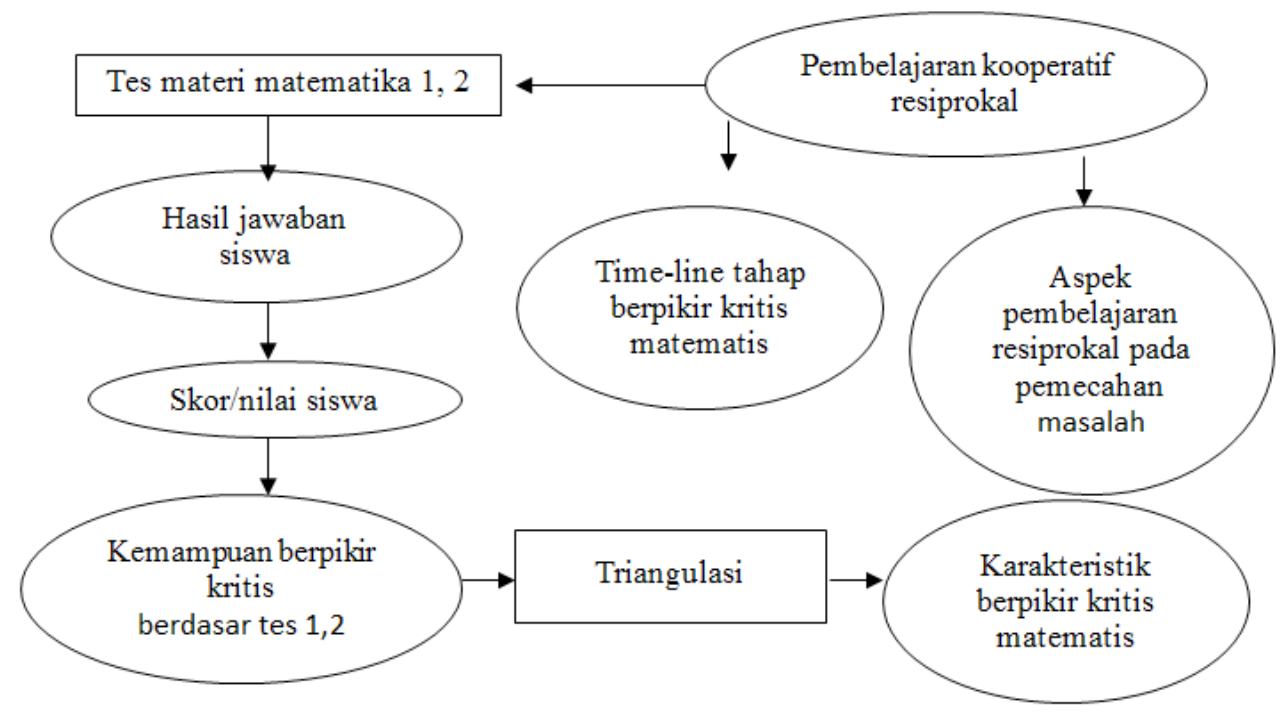

Gambar 1. Alur Penelitian

kah pemecahan masalah Polya. Sumber data dalam penelitian ini adalah siswa kelas VIII di SMP Negeri 1 Ngadirejo Temanggung.

Instrumen dalam penelitian ini adalah tes matematika, instrumen aspek resiprokal dalam diskusi memecahkan masalah openended, instrumen time-line dalam kegiatan individu dalam diskusi kelompok, instrumen time-line kegiatan berpikir kritis dalam memecahkan masalah open ended. Tes disusun berdasarkan materi yang akan diteliti, yaitu berpikir kritis memecahan masalah open-ended. Proses penyusunan instrumen tes secara umum dilakukan disesuaikan dengan materi Kurikulum 2013.

Skor tertinggi tes $=100$

Skor terendah tes $=33,33$

Jangkauan $=100-33,33=66,67$

Kemampuan berpikir kritis dikelompokkan dalam 3 kategori yaitu redah, sedang, dan tinggi. = kemampuan berpikir kritis rendah, = kemampuan berpikir kritis sedang, = kemampuan berpikir kritis tinggi, = skor tes kemampuan berpikir kritis

\section{HASIL DAN PEMBAHASAN}

Hasil

\section{Pelaksanaan Pembelajaran}

Pada pembelajaran resiprokal pertama, siswa dikelompokkan ke dalam kelompok yang ter- diri dari 4- 5 siswa dengan mempertimbangkan aspek heterogen kemampuan matematika, jenis kelamin, suku, agama. Waktu yang digunakan siswa untuk berdiskusi maksimal 30 menit.

Hampir seluruh kelompok siswa mampu menyelesaikan masalah 1 dengan benar dan tepat. Pekerjaan salah satu kelompok diskusi disajikan pada gambar 3 .

Untuk menyelesaikan bagian a) masalah tersebut, siswa saling bertanya satu sama lain tentang informasi apa yang diberikan, hal apa yang ditanyakan, berapa nilai perbandingan luas daerah yang diarsir dengan luas segitiga pada gambar 1 dan 2. Ada siswa anggota kelompok diskusi yang merasa penasaran apakah perbandingan pada gambar 1 benarbenar dan pada gambar 2 benar-benar. Pada saaat ini aspek pembelajaran resiprokal yaitu bertanya benar-benar dapat dimunculkan siswa.

Selanjutnya, siswa menduga bahwa perbandingan pada gambar 1 benar-benar diperoleh dengan cara mengukur panjang dan tinggi segitiga yang diarsir dan segitiga yang tidak diarsir. Hal ini juga berlaku untuk gambar 2. Namun, siswa lain menyatakan bahwa hal tersebut tidak mungkin terjadi karena tidak ada permintaan guru untuk mengukur segitiga tersebut. Dugaan yang lain bahwa perhitungan Ayla dengan mengurangkan luas daerah yang diarsir pada segitiga 2 dan 1 yaitu adalah salah. Siswa menduga bahwa 
Perhatikan gambar berikut ini. Ketiga segitiga tersebut kongruen (ukuran dan luasnya sama).

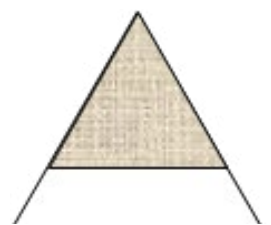

Gambar 1

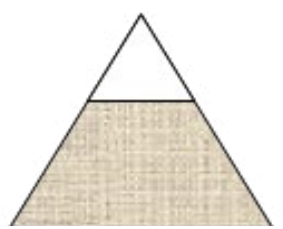

Gambar 2

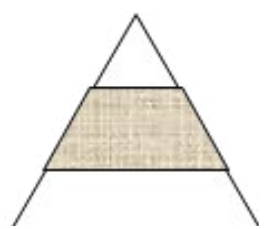

Gambar 3

Berdasarkan gambar 1 dan 2 di atas, masing-masing daerah yang diarsir menunjukkan perbandingan luasnya dengan luas segitiga. Gambar 3 belum diketahui perbandingannya. Pikirkan dan identifikasi hubungan antara perbandingan luas daerah yang diarsir pada gambar segitiga 1 dan segitiga 2 untuk mencari perbandingan luas daerah yang diarsir pada segitiga 3.

a. Untuk memperoleh perbandingan antara daerah yang diarsir pada segitiga 3, seorang siswa kelas VIII bernama Ayla memiliki ide penyelesaian menggunakan strategi berikut: Misalkan daerah yang diarsir pada segitiga 3 adalah $x$, maka nilai dari $x$ dapat dihitung dengan menggunakan pengurangan antara segitiga 2 dan segitiga 1 . Sehingga . Jadi perbandingan daerah yang diarsir pada segitiga 3 adalah 1:12.

Berdasarkan jawaban Ayla di atas, periksalah apakah jawaban Ayla benar atau salah. Jika menurutmu jawaban Ayla tersebut benar, berikan alasan dan pendapatmu. Jika menurutmu jawaban Ayla tersebut salah, carilah kalimat yang tidak logis yang menyebabkan pernyataan bernilai salah. Koreksilah. Betulkan pekerjaan Ayla tersebut.

b. Sekarang selesaikan soal di atas menurut ide dan caramu sendiri sehingga diperoleh hasil perbandingan luas daerah yang diarssir pada segitiga 3.

c. Rincilah rumus umum untuk mencari perbandingan luas daerah yang diarsir pada segitiga 3.

Gambar 2. Masalah Pembelajaran

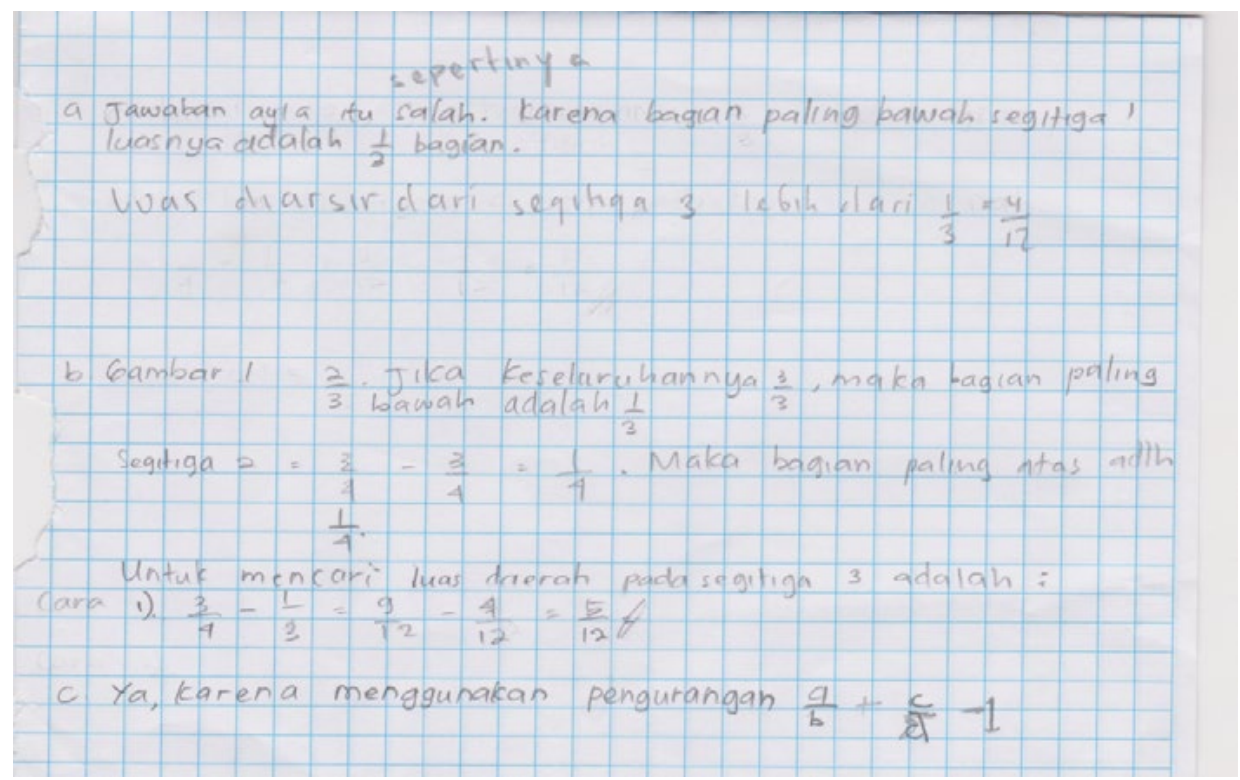

Gambar 3. Hasil pekerjaan diskusi pertemuan 1 salah satu kelompok 
luas daerah yang tidak diarsir pada segitiga 1 adalah dan bagian bawah luas daerah yang diarsir pada segitiga 3 juga. Menurut siswa, tidak mungkin luas yang diarsir pada segitiga 3 adalah karena terlihat luasnya lebih dari luas daerah yang tidak diarsir pada segitiga 3 bagian bawah yaitu. Pada saaat ini aspek pembelajaran resiprokal yaitu menduga benar-benar dapat dimunculkan siswa. Untuk menjawab bagian b), siswa mampu menjelaskan secara terperinci bagaimana jawaban diperoleh. Pada saat ini, aspek pembelajaran resiprokal yaitu menjelaskan benar-benar dapat dimunculkan siswa. Selanjutnya, siswa mampu meringkas pemecahan masalah yaitu siswa mampu menjawab bagian c) dalam bentuk umum (luas diarsir pada segitiga 1+ luas diarsir pada segitiga $2-1$ ).

Grafik time-line dalam diskusi untuk pemecahan masalah open-ended dalam pembelajaran kooperatif resiprokal.

Masalah 1 pada diskusi 1 dan masalah 2 pada diskusi 2 merupakan masalah open-ended dan merupakan masalah untuk mengukur kemampuan berpikir kritis Facione (klarifikasi, evaluasi, strategi, dan kesimpulan). Menurut Schoenfeld (1992) aktivitas pemecahan masalah matematika terdiri dari aktivitias membaca, menganalisis, mengeksplorasi, merencanakan, dan memverifikasi. Pada penelitian ini, ditinjau berapa lama (menit) siswa berpikir kritis menyelesaikan masalah 1 dan 2 dalam diskusi kelompok, berapa lama (menit) siswa melakukan aktivitas pemecahan masalah matematika. Dalam hal ini akan diperoleh grafik time-line aktivitas berpikir kritis dan grafik time line aktivitas pemecahan masalah dalam diskusi kelompok.

Grafik time-line berpikir kritis dalam diskusi kelompok pertemuan 1 disajikan dalam Gambar 3.

Berdasarkan Gambar 3, terlihat bahwa waktu yang paling lama digunakan 4 kelompok untuk berdiskusi dan berpikir kritis menyelesaikan masalah adalah pada tahap strategi. Keempat kelompok membutuhkan waktu yang lebih lama untuk memikirkan strategi apa yang akan digunakan sampai dengan menyelesaikan masalah 1 menggunakan strategi yang dipilih. Siswa dalam kelompok mengajukan langkah-langkah khusus untuk menyelesaikan, mendiskusikan langkah-langkah penyelesaian yang mungkin, mengevaluasi langkah penyelesaian yang mungkin, dan memprediksi hasil dari langkah yang diajukan atau dipilih. Siswa memunculkan banyak kemungkinan strategi yang digunakan, mencoba-coba, memikirkan apakah strategi yang digunakan tepat atau tidak. Hal ini berdampak pada lamanya waktu berpikir kritis tahap strategi.

Pada pertemuan 2 dengan materi luas daerah segitiga dan segiempat, ada 6 kelompok diskusi yang masing-masing kelompok terdiri dari 4-5 siswa. Kelompok diberikan masalah 2, dan setiap siswa diamati waktu yang mereka perlukan untuk berpikir kritis dan melakukan aktivitas pemecahan masalah matematika. Selanjutnya dihitung rata-rata waktu yang diperlukan setiap kelompok untuk berpikir kritis dan melakukan aktivitas pemecahan masalah matematika. Grafik time-line berpikir kritis dalam diskusi kelompok pertemuan 2 disajikan dalam Gambar 4.

Berdasarkan Gambar 4, terlihat bahwa hanya ada 1 kelompok siswa yang membutuh-

\section{Time-line Berpikir kritis}

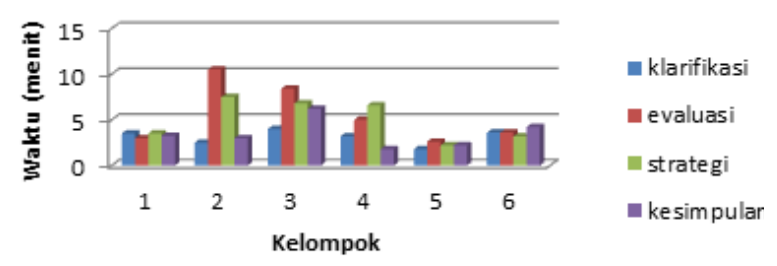

Gambar 3. Grafik time-line berpikir kritis dalam diskusi kelompok pertemuan 1 
kan waktu lebih lama untuk melakukan tahap strategi. Namun terdapat 3 kelompok yang memerlukan waktu lebih lama untuk melakukan tahap evaluasi. Tahap evaluasi merupakan tahap menilai aspek-aspek seperti membuat keputusan pada situasi, mengemukakan fakta-fakta argumen atau menghubungkan masalah dengan masalah yang lain. Siswa pada ketiga kelompok tersebut membutuhkan waktu lebih lama untuk menghubungkan luas daerah pada masalah 2 yaitu menghubungkan antara luas daerah trapesium siku-siku dengan luas daerah segitiga dan luas daerah jajargenjang.

Aktivitas pemecahan masalah matematika yang dilakukan siswa dalam diskusi kelompok adalah membaca, menganalisis, mengeksplorasi, merencanakan, dan memverifikasi. Aktivitas pemecahan masalah pada masalah 1 pertemuan 1 disajikan dalam Gambar 5 .

Berdasarkan Gambar 5, terlihat bahwa siswa dalam maisng-masing kelompok membutuhkan waktu lebih dari 2 menit dan kurang dari 7 menit untuk melakukan masing-masing aktivitas pemecahan masalah matematika. Masalah yang diberikan pada masalah 1 merupakan masalah open-ended (mempunyai banyak cara penyelesaian) dan masalah nonrutin (karena digunakan untuk mengukur berpikir kritis). Secara keseluruhan, siswa melakukan aktivitas pemecahan masalah untuk memperoleh jawaban yang benar dan tepat.

Aktivitas pemecahan masalah pada masalah 2 pertemuan 2 disajikan dalam Gambar 6.

Berdasarkan Gambar 6, terlihat bahwa pada diskusi 2, siswa dalam masing-masing kelompok membutuhkan waktu lebih dari 2 menit untuk melakukan masing-masing aktivitas pemecahan masalah matematika. Masalah yang diberikan pada masalah 2 merupakan masalah open-ended (mempunyai banyak cara penyelesaian) dan masalah non-rutin (karena digunakan untuk mengukur berpikir kritis). Secara keseluruhan, siswa melakukan aktivitas pemecahan masalah untuk memperoleh jawaban yang benar dan tepat.

\section{Time-line Aktivitas Pemecahan Masalah}
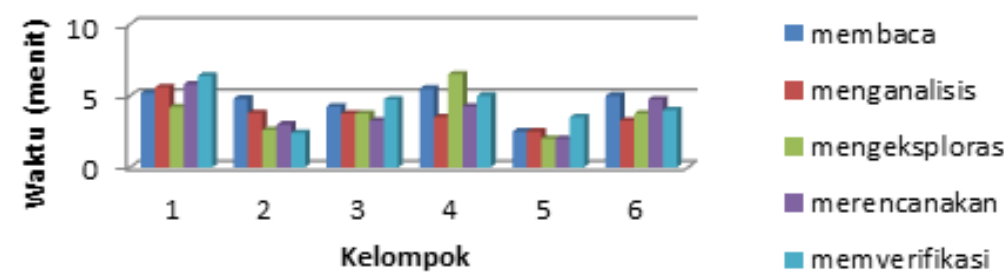

Gambar 5 Grafik Time-line aktivitas pemecahan masalah pada masalah 1

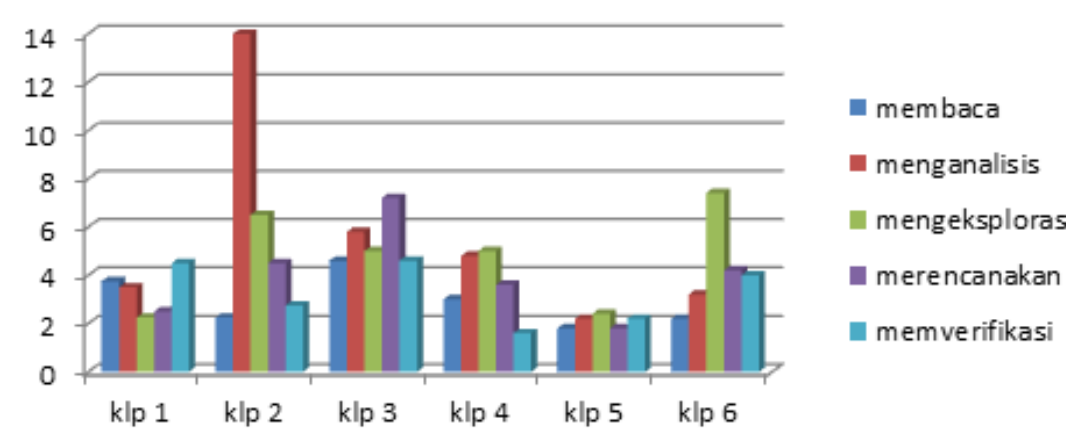

Gambar 6. Grafik Time-line aktivitas pemecahan masalah pada masalah 2 
Berdasarkan hasil penelitian di atas, berikut ini ringkasan untuk menjawab rumusan masalah 1. Berdasarkan grafik time-line tahap berpikir kritis siswa dalam menyelesaikan masalah pada diskusi 1, diperoleh fakta bahwa 4 kelompok diskusi melakukan tahap strategi pada berpikir kritis lebih lama dibandingkan tahap berpikir kritis lainnya (klarifikasi, simpulan, dan strategi). Keempat kelompok membutuhkan waktu yang lebih lama untuk memikirkan strategi apa yang akan digunakan sampai dengan menyelesaikan masalah 1 menggunakan strategi yang dipilih. Siswa dalam kelompok mengajukan langkah-langkah khusus untuk menyelesaikan, mendiskusikan langkah-langkah penyelesaian yang mungkin, mengevaluasi langkah penyelesaian yang mungkin, dan memprediksi hasil dari langkah yang diajukan atau dipilih. Siswa memunculkan banyak kemungkinan strategi yang digunakan, mencoba-coba, memikirkan apakah strategi yang digunakan tepat atau tidak. Hal ini berdampak pada lamanya waktu berpikir kritis tahap strategi. Fakta ini didukung pula fakta bahwa waktu yang dibutuhkan semua kelompok untuk berpikir kritis adalah waktu untuk tahap berpikir kritis strategi.

Berdasarkan grafik time-line tahap berpikir kritis siswa dalam menyelesaikan masalah pada diskusi 2, diperoleh fakta bahwa 1 kelompok diskusi melakukan tahap strategi pada berpikir kritis lebih lama dibandingkan tahap berpikir kritis lainnya (klarifikasi, simpulan, dan strategi). Sedangkan 3 kelompok lainnya melakukan tahap evaluasi pada berpikir kritis lebih lama dibandingkan tahap lainnya. Fakta ini didukung pula fakta bahwa waktu yang dibutuhkan semua kelompok untuk berpikir kritis adalah waktu untuk tahap berpikir kritis evaluasi.

Aktivitas pemecahan masalah matematika yang dilakukan siswa dalam diskusi kelompok adalah membaca, menganalisis, mengeksplorasi, merencanakan, dan memverifikasi. Pada diskusi 1 , siswa dalam masingmasing kelompok membutuhkan waktu lebih dari 2 menit dan kurang dari 7 menit untuk melakukan masing-masing aktivitas pemecahan masalah matematika. Waktu yang digunakan untuk melakukan aktivitas pemecahan masalah 1 diskusi 1 seluruh kelompok disku- si (1 sampai 6) adalah lebih dari 3 menit dan kurang dari 5 menit. Untuk menyelesaikan masalah 1, siswa membutuhkan waktu membaca soal paling lama dibandingkan aktivitas lainnya. Pada diskusi 2, siswa dalam maisngmasing kelompok membutuhkan waktu lebih dari 2 menit untuk melakukan masing-masing aktivitas pemecahan masalah matematika. Waktu yang digunakan untuk melakukan aktivitas pemecahan masalah 2 diskusi 1 seluruh kelompok diskusi (1 sampai 6) adalah lebih dari 2 menit kurang dari 6 menit. Untuk menyelesaikan masalah 2, siswa membutuhkan waktu menganalisis paling lama dibandingkan aktivitas lainnya.

Langkah-langkah kegiatan pemecahan masalah open-ended dalam diskusi kelompok pada pembelajaran kooperatif resiprokal

Untuk memecahkan masalah 1, pada langkah pertama yaitu memahami masalah. Pada langkah ini siswa dominan melakukan aktivitas memprediksi dan menjelaskan. Pada langkah kedua yaitu merencanakan penyelesaian, siswa dominan melakukan kegiatan bertanya dan memprediksi. Pada langkah ketiga yaitu melaksanakan penyelesaian, siswa domina melakukan kegiatan menjelaskan dan bertanya. Sedangkan pada langkah keempat yaitu mengecek kembali, siswa dominan melakukan kegiatan meringkas dan memprediksi.

Untuk memecahkan masalah 2, pada langkah pertama yaitu memahami masalah. Pada langkah ini siswa dominan melakukan aktivitas memprediksi dan bertanya. Pada langkah kedua yaitu merencanakan penyelesaian, siswa dominan melakukan kegiatan menjelaskan dan bertanya. Pada langkah ketiga yaitu melaksanakan penyelesaian, siswa dominan melakukan kegiatan memprediksi. Sedangkan pada langkah keempat yaitu mengecek kembali, siswa dominan melakukan kegiatan menjelaskan dan memprediksi.

Berikut ini hasil rangkuman aspek-aspek pembelajaran resiprokal pada pemecahan masalah matematika pertemuan 1 dan 2. Untuk memecahkan masalah matematika, pada langkah pertama yaitu memahami ma- 
salah. Pada langkah ini siswa dominan melakukan aktivitas bertanya dan memprediksi. Pada langkah kedua yaitu merencanakan penyelesaian, siswa dominan melakukan kegiatan bertanya dan menjelaskan. Pada langkah ketiga yaitu melaksanakan penyelesaian, siswa dominan melakukan kegiatan menjelaskan dan bertanya. Sedangkan pada langkah keempat yaitu mengecek kembali, siswa dominan melakukan kegiatan menjelaskan.

\section{Karakteristik berpikir kritis siswa dalam} menyelesaikan masalah open-ended

Berpikir kritis pada penelitian ini adalah berpikir kritis Perkins dan Murphy yang tahap berpikir kritisnya adalah klarifikasi, evaluasi, penyimpulan dan strategi/taktik. Untuk tahap klarifikasi yaitu tahap menyatakan, mengklarifikasi,menggambarkan atau mendefinisi masalah. Pada tahap ini akan dilihat indikator mendefinisikan istilah yang relevan. Tahap evaluasi merupakan tahap menilai aspek-aspek seperti membuat keputusan pada situasi, mengemukakan fakta-fakta argumen atau menghubungkan masalah dengan masalah yang lain. Indikator pada tahap ini adalah mendapatkan dan menilai informasi yang relevan. Tahap penyimpulan tahap dimana siswa dapat menunjukkan hubungan diantara sejumlah ide, menggambarkan kesimpulan yang tepat dengan deduksi dan induksi, menggeneralisasi, menjelaskan dan membuat hipotesis. Indikator pada tahap ini adalah membuat kerangka hubungan diantara bagian-bagian masalah yang berbeda. Tahap strategi/taktik merupakan tahap mengajukan, mengevaluasi sejumlah tindakan yang mungkin. Indikator pada tahap ini adalah mengajukan langkah-langkah tertentu untuk mendapatkan penyelesaian.

Untuk mendapatkan karakteristik berpikir kritis siswa, siswa diberikan 2 kali tes. Kedua tes tersebut berfungsi sebagai triangulasi (triangulasi dengan alat) untuk mendapatkan karakteristik berpikir kritis. Hasil dari tes 1 dibandingkan (triangulasi) dengan hasil tes 2.

Tes 1 dilaksanakan pada tanggal 27 Agustus 2015. Soal tes 1 berkaitan dengan luas bangun datar yang sama dengan luas jajargenjang. Skor tertinggi adalah 100 dan skor terendah adalah 10. Penilaian tes 1 berdasarkan indikator berpikir kritis Perkins dan Murphy. Untuk mendapatkan karakteristik berpikir kritis siswa dipilih 3 siswa yang masing-masing mewakili kemampuan berpikir kritis tinggi, sedang, dan rendah. Siswa yang mendapatkan skor $(x)$ dikategorikan memiliki kemampuan berpikir kritis rendah, skor dikategorikan memiliki kemampuan berpikir kritis sedang, dan skor 7 dikategorikan memiliki kemampuan berpikir kritis tinggi.

Pertanyaan pada tes 1 adalah gambarkan paling sedikit tiga bangun datar yang berbeda-beda memiliki luas yang sama dengan luas jajargenjang PQRS pada gambar di samping.

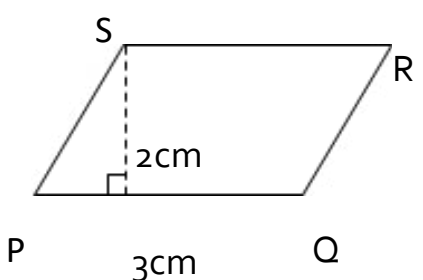

Berdasarkan skor tes 1, SA mendapatkan skor 100 dan termasuk dalam kategori berkemampuan berpikir kritis tinggi. Pada tahap klarifikasi, SA mampu mendefinisikan istilah yang relevan yaitu istilah bangun datar pada soal diterjemahkan sebagai persegi panjang, trapesium, segitiga, dan layang-layang. $\mathrm{Hal}$ ini terlihat dari beberapa gambar bangun datar tersebut. Pada tahap evaluasi, SA mampu mendapatkan dan menilai informasi yang relevan yaitu rumus umum luas daerah persegi panjang, luas daerah trapesium, luas daerah segitiga, dan luas daerah layang-layang. Pada tahap simpulan, SA mampu membuat kerangka hubungan diantara bagian-bagian masalah yang berbeda yaitu menghitung luas daerah jajar genjang lalu membuat bangunbangun lain dan ukuran-ukurannya sehingga luasnya 6. Pada tahap strategi, SA mampu mengajukan langkah-langkah tertentu untuk mendapatkan penyelesaian yaitu membuat gambar bangun datar, menentukan ukuranukuran bangun datar tersebut lalu menghitung luasnya. Gambar berikut ini menunjukkan langkah-langkah pekerjaan SA.

Berdasarkan tes 1 , diperoleh simpulan 


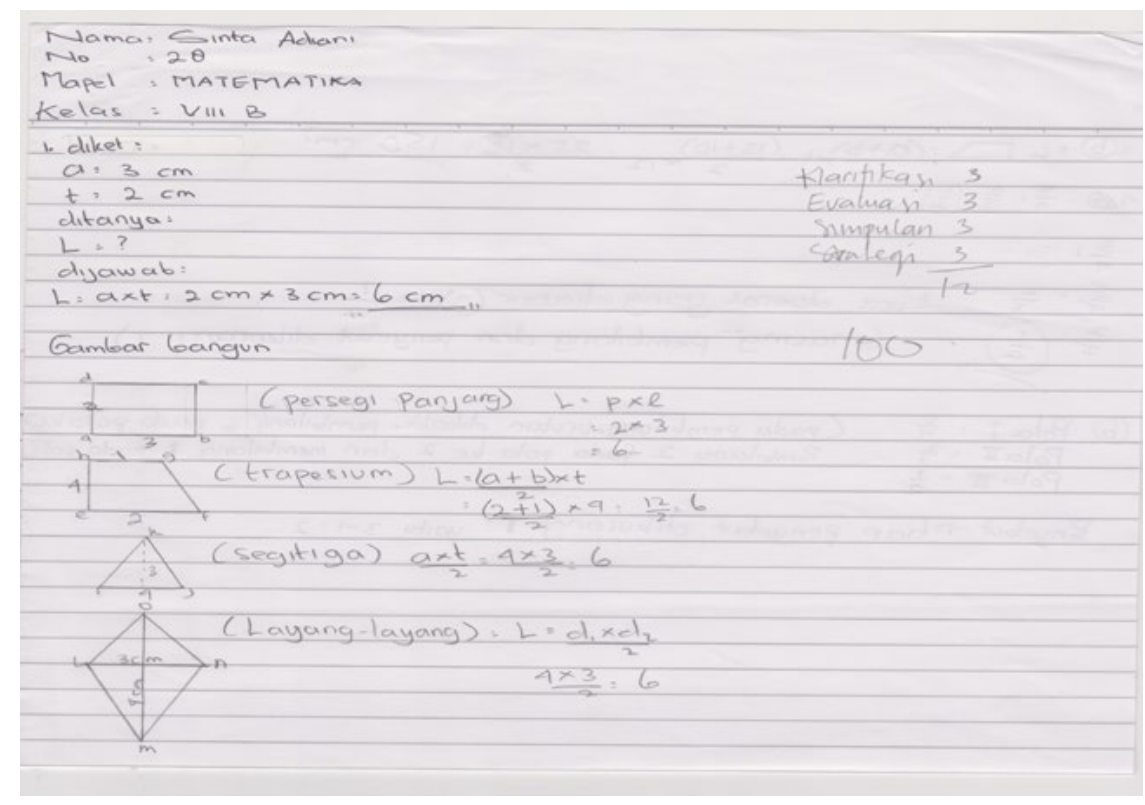

Gambar 7. Pekerjaan siswa SA

Tabel 1. Triangulasi karakteristik berpikir kritis tinggi berdasarkan tes 1 dan tes 2

\begin{tabular}{llll}
\hline & Simpulan tes 1 & \multicolumn{1}{c}{ Simpulan tes 2 } & \multicolumn{1}{c}{ Simpulan } \\
\hline Klarifikasi & Sempurna & Sempurna & Sempurna \\
Evaluasi & Sempurna & $\begin{array}{l}\text { Kurang sempurna s.d } \\
\text { Sempurna }\end{array}$ & Kurang sempurna s.d \\
& & Sempurna \\
Simpulan & Sempurna & Sempurna & Sempurna \\
Strategi & Sempurna & Kurang Sempurna & Kurang sempurna s.d \\
& & & Sempurna \\
\hline
\end{tabular}

Tabel 2. Triangulasi karakteristik berpikir kritis sedang berdasarkan tes 1 dan tes 2

\begin{tabular}{|c|c|c|c|}
\hline & Simpulan tes 1 & Simpulan tes 2 & Simpulan \\
\hline Klarifikasi & Sempurna & $\begin{array}{l}\text { Kurang sempurna s.d } \\
\text { Sempurna }\end{array}$ & $\begin{array}{l}\text { Kurang sempurna s.d } \\
\text { Sempurna }\end{array}$ \\
\hline Evaluasi & $\begin{array}{l}\text { Tidak sempurna s.d } \\
\text { Kurang sempurna }\end{array}$ & $\begin{array}{l}\text { Kurang sempurna s.d } \\
\text { Sempurna }\end{array}$ & $\begin{array}{l}\text { Tidak sempurna s.d } \\
\text { Sempurna }\end{array}$ \\
\hline Simpulan & $\begin{array}{l}\text { Kurang Sempurna s.d } \\
\text { Sempurna }\end{array}$ & Kurang Sempurna & Kurang Sempurna \\
\hline Strategi & Kurang Sempurna & Kurang Sempurna & Kurang Sempurna \\
\hline
\end{tabular}

Tabel 3. Triangulasi karakteristik berpikir kritis rendah berdasarkan tes 1 dan tes 2

\begin{tabular}{llll}
\hline & \multicolumn{1}{c}{ Simpulan tes 1 } & \multicolumn{1}{c}{ Simpulan tes 2 } & \multicolumn{1}{c}{ Simpulan } \\
\hline Klarifikasi & $\begin{array}{l}\text { Tidak Sempurna s.d } \\
\text { Kurang sempurna }\end{array}$ & Tidak sempurna & Tidak Sempurna s.d \\
Evaluasi & Tidak sempurna & Tidak sempurna & $\begin{array}{l}\text { Kurang sempurna } \\
\text { Simpulan }\end{array}$ \\
Strategi & Tidak sempurna & Tidak sempurna & Tidak sempurna \\
\hline
\end{tabular}


karakteristik berpikir kritis tinggi, sedang, dan rendah dari 2 subjek. Hal demikian juga berlaku untuk tes 2. Selanjutnya dilakukan triangulasi karakteristik berpikir kritis tinggi, sedang, dan rendah berdasarkan tes 1 dan 2 sebagaimana disajikan dalam Tabel 1, Tabel 2, dan Tabel 3 .

\section{PEMBAHASAN}

Pada penelitian ini, setiap siswa dalam satu kelompok dicatat waktu yang mereka perlukan untuk berpikir kritis menyelesaikan masalah pada diskusi 1 maupun 2. Setiap siswa dicatat waktu yang mereka perlukan dalam tahap berpikir kritis yaitu klarifikasi, evaluasi, simpulan, dan strategi. Artinya bahwa setiap siswa harus terlibat dalam aktivitas berpikir kritis dalam setingan diskusi, tidak bergantung pada siswa lain. Hal ini dikarenakan berpikir kritis merupakan proses dan belajar matematika juga menekankan pada proses bukan hasil/produk. Hal ini senada dengan pernyataan Paul \& Nosick (dalam Palmer, 2007) yang mendefinisikan berpikir kritis sebagai proses intelektual untuk menganalisis, menerapkan, mensintesis atau mengevaluasi informasi yang diperoleh berdasarkan pengamatan, pengalaman, refleksi, penalaran ataupun komunikasi dan Perkins \& Murphy (2006) yang menyatakan bahwa berpikir kritis melalui tahap berpikir yaitu klarifikasi, evaluasi, simpulan, dan strategi.

Settingan diskusi dalam penelitian ini membuat siswa aktif berpikir kritis. Hal ini senada dengan pernyataan Kanuka (dalam Mokoena, 2013) menyatakan bahwa forum diskusi dapat meningkatkan kemampuan berpikir kritis siswa. Pernyataan ini didukung oleh Perkins dan Murphy (2006) yang mengembangkan model mengukur berpikir kritis dalam diskusi.

Setiap siswa dicatat waktu yang mereka gunakan untuk berpikir kritis menyelesaikan masalah 1 maupun 2 dalam diskusi 1 dan 2. Pada diskusi 1, terlihat siswa dalam 4 kelompok diskusi melakukan tahap strategi yang lama dibandingkan tahap klarifikasi, evaluasi dan simpulan. Namun di diskusi 2, hanya siswa dalam 1 kelompok yang masih lama melakukan tahap strategi. Hal ini menunjukkan bahwa siswa telah terbiasa melakukan proses berpikir kritis. Hal ini senada dengan pernyataan para ahli yaitu Ennis,1992; Halpern, 1993; Paul, 1993; Perkins \& Salomon, 1989 (dalam Reed, 1998) yang menyatakan bahwa kemampuan berpikir kritis secara umum dapat diajarkan/dibiasakan dalam berbagai settingan.

Pada diskusi 1, siswa membutuhkan waktu lama dalam tahap klarifikasi sedangkan pada diskusi 2 siswa lama dalam tahap evaluasi. Hal ini wajar karena berpikir kritis merupakan proses dan tidak berkembang dalam jangka waktu singkat. Hal ini didukung pernyataan Van Gelder (Orszag, 2015) bahwa berpikir kritis tidak berkembang dalam 1 malam dan terkadang membutuhkan proses yang lama. Selain itu, berpikir kritis membutuhkan aktivitas-aktivitas mental. Siswa masih belum terbiasa melakukan aktivitas mental. Hal ini didukung pernyataan Lipman (dalam Orszag, 2015) yang menyatakan bahwa berpikir kritis dikembangkan dengan cara mengembangkan aktivitas mental. Sebagai contoh untuk dapat mengambil keputusan, diperlukan aktivitas mental seperti menduga, memilih, atau menerima perbedaan.

Aktivitas pemecahan masalah matematika yang dilakukan siswa dalam diskusi kelompok adalah membaca, menganalisis, mengeksplorasi, merencanakan, dan memverifikasi. Pada diskusi 1, siswa dalam masingmasing kelompok membutuhkan waktu lebih dari 2 menit dan kurang dari 7 menit untuk melakukan masing-masing aktivitas pemecahan masalah matematika. Waktu yang digunakan untuk melakukan aktivitas pemecahan masalah 1 diskusi 1 seluruh kelompok diskusi (1 sampai 6) adalah lebih dari 3 menit dan kurang dari 5 menit. Untuk menyelesaikan masalah 1, siswa membutuhkan waktu membaca soal paling lama dibandingkan aktivitas lainnya.

Pada diskusi 2, siswa dalam masingmasing kelompok membutuhkan waktu lebih dari 2 menit untuk melakukan masing-masing aktivitas pemecahan masalah matematika. Waktu yang digunakan untuk melakukan aktivitas pemecahan masalah 2 diskusi 1 seluruh kelompok diskusi (1 sampai 6) adalah lebih dari 2 menit kurang dari 6 menit. Untuk menyelesaikan masalah 2, siswa membutuhkan 
waktu menganalisis paling lama dibandingkan aktivitas lainnya.

Waktu yang digunakan siswa dalam aktivitas pemecahan masalah pada penelitian ini cenderung cepat. Padahal penelitian yang dilakukan oleh Schoenfeld (1962) menemukan fakta bahwa ketika siswa diberikan soal non-rutin, siswa membaca soal lalu berusaha mencari strategi penyelesaian. Aktivitas pemecahan masalah (membaca, menganalisis, mengeksplorasi, merencanakan, memverifikasi) yang dilakukan siswa hanya membaca dan mengeksplorasi. Namun pada akhir waktu mengerjakan (20 menit) siswa tidak dapat menyelesaikannya.

Untuk memecahkan masalah matematika, pada langkah pertama yaitu memahami masalah. Pada langkah ini siswa dominan melakukan aktivitas bertanya dan memprediksi. Kenyataan ini didukung pernyataan Polya (1973), bahwa memahami masalah diawali dengan memahami pernyataan verbal dari masalah itu sendiri. Untuk dapat memahami masalah, siswa harus mengetahui bagianbagian terperinci dari masalah, apa yang tidak diketahui, data yang diperlukan, kondisi yang ada. Hal ini dilakukan dengan cara bertanya. Department of Education and Early Childhood Development DEECD 2008 \& 2007 dan Department of Education and Training (DET, 2006) (dalam Reilly, Parsons, \& Bortolot, 2009) juga menyatakan bahwa untuk memahami masalah dilakukan dengan menggali pengertian yang ada dalam teks dan hal ini dilakukan dengan mengajukan pertanyaan. Dengan bertanya, siswa akan memonitor pemahaman mereka.

Pada saat memahami masalah, siswa dominan pada aktivitas memprediksi. Siswa mengaitkan konsep dari masalah dengan konsep-konsep yang dipelajari untuk memprediksi langkah-langkah penyelesaian masalah. Hal ini didukung pernyataan Doolittle, dkk (2006) menyatakan bahwa memprediksi melibatkan pengetahuan awal yang sudah dimiliki siswa dan pengetahuan baru yang muncul dalam teks masalah dan digunakan untuk membuat hipotesis/dugaan berkaitan dengan apa yang ditanyakan.

Pada langkah kedua dan ketiga yaitu merencanakan penyelesaian dan melaksana- kan penyelesaian, siswa dominan melakukan kegiatan bertanya dan menjelaskan. Siwa satu dan lainnya saling menjelaskan konsep yang ada dalam teks masalah maupun konsep yang akan digunakan dalam menyelesaikan masalah. Aktivitas bertanya dan menjelaskan ini dominan dikarenakan ada siswa yang mengalami kesulitan mengidentifikasi aspekaspek yang tidak jelas/sulit dimengerti/tidak familiar dalam teks masalah. Oleh karena itu siswa bertanya baik kepada teman 1 kelompok maupun kepada guru. Selanjutnya guru maupun teman satu kelompoknya memberikan penjelasan. Kenyataan ini didukung oleh Doolittle, dkk (2006) yang menyatakan bahwa menjelaskan melibatkan identifikasi dan klarifikasi terhadap aspek-aspek yang tidak jelas/ susah/tidak familiar dari suatu teks masalah. Mereka juga saling bertanya strategi apa yang akan dipilih untuk menyelesaikan masalah. Hal ini dilakukan agar penyelesaian masalah siswa benar dan tepat.

Sedangkan pada langkah keempat yaitu mengecek kembali, siswa dominan melakukan kegiatan menjelaskan. Siswa saling menjelaskan satu dengan lain algoritma yang digunakan benar atau tidak dan hasil yang diperoleh benar atau tidak. Komunikasi aktif ini sangat membantu siswa menguasai konsep yang dipelajari.

Karakteristik subjek yang dikategorikan memiliki kemampuan berpikir kritis tinggi adalah 1) siswa sempurna melakukan tahap klarifikasi, 2) siswa kurang sempurna sampai dengan sempurna melakukan tahap evaluasi, 3) siswa sempurna melakukan tahap simpulan, dan 4) kurang sempurna sampai dengan sempurna melakukan tahap strategi. Karakteristik subjek yang dikategorikan memiliki kemampuan berpikir kritis sedang adalah 1) siswa kurang sempurna sampai dengan sempurna sempurna melakukan tahap klarifikasi, 2) siswa tidak sempurna sampai dengan sempurna melakukan tahap evaluasi, 3) siswa kurang sempurna melakukan tahap simpulan, dan 4) kurang sempurna sampai dengan sempurna melakukan tahap strategi. Karakteristik subjek yang dikategorikan memiliki kemampuan berpikir kritis rendah adalah 1) siswa tidak sempurna sampai dengan kurang sempurna sempurna melakukan tahap klarifikasi, 
2) siswa tidak sempurna melakukan tahap evaluasi, 3) siswa tidak sempurna melakukan tahap simpulan, dan 4) siswa tidak sempurna melakukan tahap strategi.

Berdasarkan hasil penelitian karakteristik berpikir kritis dalam memecahkan masalah matematika di atas, terlihat bahwa ada proses dalam berpikir kritis. Siswa yang berkemampuan berpikir kritis tinggi, dalam tahap evaluasi ada yang dapat melakukan tahap ini dengan sempurna namun ada pula yang kurang sempurna. Demikian pula untuk tahap lainnya. Kenyataan ini didukung oleh pendapat para ahli diantaranya Brookfield, 1987; Garrison, 1992 (dalam Schellens, tanpa tahun). Menurut mereka, berpikir kritis merupakan proses memecahkan masalah. Garrison juga membuat tahapan dalam berpikir kritis yang berbeda dengan tahap berpikir kritis Perkins dan Murphy. Garrison (dalam Schellens, tanpa tahun ) mengidentifikasi 5 tahap berpikir kritis. Menurutnya, seorang pemikir kritis akan melalui tahap identifikasi masalah, mengidentifikasi masalsah dengan lebih jelas, mengeksplorasi masalah dan penyelesaian yang mungkin, mengevaluasi kemampuan mereka, dan mengintegrasikan pemahaman dan pengetahuan yang sudah mereka miliki.

\section{PENUTUP}

\section{Simpulan}

Berdasarkan hasil penelitian, disimpulkan bahwa: (a) Berdasarkan grafik time-line tahap berpikir kritis siswa dalam menyelesaikan masalah pada diskusi 1, diperoleh fakta bahwa 4 kelompok diskusi melakukan tahap strategi pada berpikir kritis lebih lama dibandingkan tahap berpikir kritis lainnya (klarifikasi, simpulan, dan strategi). Keempat kelompok membutuhkan waktu yang lebih lama untuk memikirkan strategi apa yang akan digunakan sampai dengan menyelesaikan masalah 1 menggunakan strategi yang dipilih. Fakta ini didukung pula fakta bahwa waktu yang dibutuhkan semua kelompok untuk berpikir kritis adalah waktu untuk tahap berpikir kritis strategi. Berdasarkan grafik time-line tahap berpikir kritis siswa dalam menyelesaikan masalah pada diskusi 2, diperoleh fakta bahwa 1 kelompok diskusi melakukan tahap strategi pada berpikir kritis lebih lama dibandingkan tahap berpikir kritis lainnya (klarifikasi, simpulan, dan strategi). Sedangkan 3 kelompok lainnya melakukan tahap evaluasi pada berpikir kritis lebih lama dibandingkan tahap lainnya. Fakta ini didukung pula fakta bahwa waktu yang dibutuhkan semua kelompok untuk berpikir kritis adalah waktu untuk tahap berpikir kritis evaluasi. Aktivitas pemecahan masalah matematika yang dilakukan siswa dalam diskusi kelompok adalah membaca, menganalisis, mengeksplorasi, merencanakan, dan memverifikasi. Pada diskusi 1, siswa dalam masingmasing kelompok membutuhkan waktu lebih dari 2 menit dan kurang dari 7 menit untuk melakukan masing-masing aktivitas pemecahan masalah matematika. Waktu yang digunakan untuk melakukan aktivitas pemecahan masalah 1 diskusi 1 seluruh kelompok diskusi (1 sampai 6) adalah lebih dari 3 menit dan kurang dari 5 menit. Untuk menyelesaikan masalah 1, siswa membutuhkan waktu membaca soal paling lama dibandingkan aktivitas lainnya. Pada diskusi 2, siswa dalam masingmasing kelompok membutuhkan waktu lebih dari 2 menit untuk melakukan masing-masing aktivitas pemecahan masalah matematika. Waktu yang digunakan untuk melakukan aktivitas pemecahan masalah 2 diskusi 1 seluruh kelompok diskusi (1 sampai 6) adalah lebih dari 2 menit kurang dari 6 menit. Untuk menyelesaikan masalah 2, siswa membutuhkan waktu menganalisis paling lama dibandingkan aktivitas lainnya. (b) Untuk memecahkan masalah matematika, pada langkah pertama yaitu memahami masalah. Pada langkah ini siswa dominan melakukan aktivitas bertanya dan memprediksi. Pada langkah kedua yaitu merencanakan penyelesaian, siswa dominan melakukan kegiatan bertanya dan menjelaskan. Pada langkah ketiga yaitu melaksanakan penyelesaian, siswa dominan melakukan kegiatan menjelaskan dan bertanya. Sedangkan pada langkah keempat yaitu mengecek kembali, siswa dominan melakukan kegiatan menjelaskan; (c) Karakteristik subjek yang dikategorikan memiliki kemampuan berpikir kritis tinggi adalah 1) siswa sempurna melakukan tahap klarifikasi, 2) siswa kurang sempurna sampai dengan sempurna melakukan tahap evaluasi, 3) siswa sempurna melakukan tahap 
simpulan, dan 4) kurang sempurna sampai dengan sempurna melakukan tahap strategi. Karakteristik subjek yang dikategorikan memiliki kemampuan berpikir kritis sedang adalah 1) siswa kurang sempurna sampai dengan sempurna sempurna melakukan tahap klarifikasi, 2) siswa tidak sempurna sampai dengan sempurna melakukan tahap evaluasi, 3) siswa kurang sempurna melakukan tahap simpulan, dan 4) kurang sempurna sampai dengan sempurna melakukan tahap strategi. Karakteristik subjek yang dikategorikan memiliki kemampuan berpikir kritis rendah adalah 1) siswa tidak sempurna sampai dengan kurang sempurna sempurna melakukan tahap klarifikasi, 2) siswa tidak sempurna melakukan tahap evaluasi, 3) siswa tidak sempurna melakukan tahap simpulan, dan 4) siswa tidak sempurna melakukan tahap strategi.

\section{SARAN}

Saran berdasarkan penelitian ini adalah: (a) Aktivitas pemecahan masalah (membaca, menganalisis, mengeksplorasi, merencanakan, dan memverifikasi) matematika dibiasakan dalam pembelajaran matematika di sekolah; (b) Siswa dibiasakan untuk berpikir kritis sesuai dengan tahap-tahap berpikir kritis klarifikasi, evaluasi, simpulan, dan strategi.

\section{DAFTAR PUSTAKA}

Doolittle, P. E., Hicks, D., Triplett, C. F., Nichols, W. D., \& Young, C. A. (2006). Reciprocal teaching for reading comprehension in higher education: $A$ strategy for fostering the deeper understanding of texts. International Journal of Teaching and Learning in Higher Education, 17(2), 106-118.

Ennis, R. (1996). Critical Thinking. Upper Saddle River, NJ: Prentice-Hal

Hudojo, H. (2003). Pengembangan Kurikulum dan Pembelajaran Matematika. Surabaya: UM Press.
Jacob, S. M., \& Sam, H. K. (2008, January). Critical Thinking Skills in Online Mathematics Discussion Forums and Mathematical Achievement. In Proceedings of the 13th Asian Technology Conference in Mathematics (ATCM 2008), Thailand (pp. 1519).

Krulik, S \& J.A. Rudnick. (1995). The New Sourcebook For Teaching Reasoning and Problem Solving In Elementary School. Boston: Allyn and Bacon

Mokoena, S. (2013). Engagement with and participation in online discussion forums. TOJET: The Turkish Online Journal of Educational Technology, 12(2).

Moleong, L. J. (2011). Metodologi Penelitian Kualitatif. Bandung: Remaja Rosdakarya.

Orszag, A. (2015). Exploring Finnish university students' perceived level of critical thinking.

Palmer, S. M. (2007). Critical thinking dispositions of parttime faculty members teaching at the college level. ProQuest.

Perkins, C., \& Murphy, E. (2006). Identifying and measuring individual engagement in critical thinking in online discussions: An exploratory case study. Educational Technology \& Society, 9(1), 298-307.

Polya, G. (1973). How to Solve It: A new Aspct of Mathematical Method Second Edition. Princeton University Press: Princeton, New Jersey

Reed, J. H. (1998). Effect of a Model for Critical Thinking on Student Achievement in Primary Source Document Analysis and Interpretation, Argumentative Reasoning, Critical Thinking Dispositions, and History Content in a Community College History Course. Disertasi. Florida: University of South Florida.

Reilly, Y., Parsons, J., \& Bortolot, E. (2009). Reciprocal teaching in mathematics. Mathematics of prime importance, Sunshine College, Victoria 8, 182-189.

Schoenfeld, A. H. (1992). Learning to think mathematically: Problem solving, metacognition, and sense making in mathematics. Handbook of research on mathematics teaching and learning, 334-370.

Schellens, T., Van Keer, H., De Wever, B., \& Valcke, M. (2009). Tagging thinking types in asynchronous discussion groups: Effects on critical thinking. Interactive Learning Environments, 17(1), 77-94. 